\title{
Snesitelná těžkost nebytí/bytí obchodního práva
}

\section{The Bearable Toughness of Not-Being/Being of Commercial Law}

\author{
Josef Bejček
}

\begin{abstract}
Abstrakt
Obchodni právo bylo zbaveno v roce 2012 kodexové základny svébo rozvoje, podobnè jako hospodárské právo $v$ roce 1991. O strukture a obsabu výnky právnich disciplín (a ani o členèni na tẓ. odvètvi právni) ovšem formálni právni prameny nerozhoduji. Výuka moderníbo obchodního práva proto i dnes, po opusténi konceptu samostatnébo práva hospodárského, zahrnuje nejen prǒslušné segmenty soukromoprávni civilistiky, ale vènuje se i základuim veřejnoprávnich regulatornich úprav vұtahujicich se k obchodu a podnikání. Obchody se tradičně chápou (a i vyưujî) ve dvou smyslech: v ư̌šrim, stavovském (subjektivnim), jako právem regulovaný styk. prǐslusnikiu stavu obchodnického, tedy tèch, kterým právo prǐznává status obchodnika (podnikatele). Drubé (objektivni) pojeti zdiraznnuje tzv. obchody, jakožto typické akty oběbu statkư, k nimž dochází bez obledu na osobní podnikatelský ci nepodnikatelský status účastniku. Dilcí prekerýváni a doplnováni s právem občanským zejména v oblasti sjednocenébo práva závąkovébo je prínosem. Obecnèjsím požadavküm na nároky

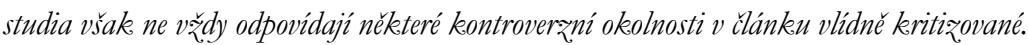

\section{Klíčová slova}

Obchodni právo; hospodárské právo; občanské právo; obcanský qákonik; bospodárský qákoník; právni regulace obchodu a podnikáni; některé obsahové a formálni standardy výnky práva.

\begin{abstract}
Commercial Law was deprived of its own Code in 2012, similarly as it happened to the Economic Law in 1991. Nevertheless, formal sources of law predetermine neither the structure and content of legal disciplines, nor the division of legal system into legal branches. Tuition of modern commercial law involves therefore even today, after quitting the "socialist" concept of separate economic law, not only traditional segments of private (civil) law but basics of public law regulations related to business and entrepreneurship, too. Businesses are traditionally understood and tought in two meanings - both as subject-conditioned contact of entrepreneurs and as a typical exchange of goods regardless of entrepreneurial or non-entrepreneurial status of persons concerned. Partial overlapping of commercial and general civil laws and complementing each other is beneficial, especially in the field of recently unified law of obligations. General demanding study requirements do not always comply with several controversial circumstances we are facing in our universities nowadays; some of these factors are subject to benign criticism in the essay.
\end{abstract}

\section{Keywords}

Commercial Law; Socialist Economic Law; Civil Law; Civil Code; Economic Code; Legal Regulation of Business and Entrepreneurial Activities; Some Content-Related and Formal Standards of Legal Studies.

\footnotetext{
* Prof. JUDr. Josef Bejček, CSc., Katedra obchodního práva, Právnická fakulta, Masarykova univerzita, Brno / Department of Commercial Law, Faculty of Law, Masaryk University, Brno, Czech Republic / E-mail: Josef.Bejcek@law.muni.cz / ORCID: 0000-0002-9059-2630
} 


\section{Úvod}

V duchu Balzacova kréda „termín je nejlepší inspirace“ jsem očekával nápad, jak na slušné a včasné požádání redakční rady co nejlépe ve formě článečku uctít stoleté výročí naší fakulty, a to ve skromně, ale jasně stanoveném rozmezí rozsahu znaků (včetně mezer) a v daném termínu (a to bez mezery na jeho konci).

Nezáživnou faktografií vývoje katedry a oboru jsem se nechtěl zabývat; to naštěstí náleží povolanějším kolegům historikům, kteří se této role ostatně již ujali a minulost fakulty a všech jejích kateder (s využitím podkladů z kateder, s odstupem a v potřebných proporcích) popsali. ${ }^{1}$ Termín uzávěrky se blížil, ale kupodivu byv prost kýženého to mytického účinu.

Nakonec jsem byl kvůli takové nedostačivé termínové inspiraci mocen jen několika úvah o nevděčné pozici oboru obchodního práva či obecněji právní regulace ekonomiky jakožto věčného párii či otloukánka, k nimž jsem připojil hrstku postřehů a poznámek o některých „nadoborových“ bolestech, chronických patologiích a výzvách, s nimiž se potýkáme nejen na naší katedře a fakultě, ale v našem vysokém školství obecně.

Obchodní i dřivější hospodářské právo nesou neblahé znamení dosti exotického oboru, jenž je vesměs za hranicemi osobní nebo i zprostředkované zkušenosti studentů (a u těch perspektivnějších snad i před oněmi hranicemi), na rozdíl nap̌r. od práva občanského, rodinného, pracovního, trestního, správního aj., o nichž mají jakousi alespoň matnou představu mnohdy již před vstupem na fakultu.

Bláhové naděje některých romantičtějších studentů, že následkem zrušení obchodního zákoníku² po rekodifikaci soukromého práva v roce 2012 zmizí ze světa (a hlavně ze studijních plánů) rozsáhlá a náročná disciplína práva obchodního, se samožrejmě nenaplnily.

1 VOJÁČEK, L., K. SCHELLE a J. TAUCHEN. Dějiny Právnické fakulty Masarykovy univerzity 1919-2019. 1. díl 1919-1989. Brno: Masarykova univerzita, 2019, 576 s. ISBN 9788021092402. 2. díl (1990-2019) je v tisku.

2 Přestože obchodní zákoník měl podle schváleného věcného záměru občanského zákoníku (oponoval jsem jej, takže to vím přesně) zůstat jako speciální předpis vedle nového občanského zákoníku. Věcný záměr počítal s tím, že se $\mathrm{v}$ novém občanském zákoníku sjednotí obecná úprava závazkového práva a většiny typů smluv, zatímco úprava specifických otázek obchodního práva (včetně, ale nejen, práva obchodních společností a družstev) zůstane v redukovaném zákoníku obchodním. Zpětně viděno to byl asi jen taktický záměr. „Salámovou metodou“ se totiž v průběhu legislativních prací z „obchodního zákoníku“ stal nejprve „obchodní zákon“, který se později ještě redukoval v zásadě na zákon o obchodních korporacích; typické obchodně právní instituty se přenesly především do komercionalizovaného občanského zákoníku. Praxe právní i pedagogická skládá takto uměle dekomponované (dekonstruované) obchodní právo zpětně. Obor obchodního práva, jenž vznikl „překlopením“ oboru práva hospodářského, má u nás značnou frustrační toleranci. Přes zdánlivou dvojí ztrátu kodexové „půdy pod nohama“ (hospodářského zákoníku v r. 1991 a obchodního zákoníku v roce 2012) nejenže neživoří na vegetativní úrovni, ale velmi dobře se rozvíjí. I to je důkazem o jeho společenské potřebnosti; samotná vytrvalost a konzervativní tvrdohlavost učitelů by na to určitě nestačila. Některé ještě odolnější obory právní ostatně kodexovou ,půdu pod nohama“ neměly a nebudou mít nikdy, aniž by se jakkoliv zpochybňovala jejich užitečnost a potřebnost. 
Reakce na zásadní změny právních předpisů, kolem nichž byly vybudovány pedagogické obory občanského a obchodního práva, se bývala mohla pohybovat mezi krajními polohami: bud' ponechat věci „postaru“ a přizpůsobit se jen novému obsahu úprav, nebo s odkazem na nové předpisy provést ve výuce soukromého práva „revoluci“، Prosadil se vesměs pragmatický kompromisní přístup inklinující spíše k oné konzervativnější variantě. Převládl názor, že o struktuře a obsahu výuky právních disciplín (a ani o členění na tzv. odvětví právnî) formální právní prameny nerozhodují, byt' je třeba (zejména kodexy) z kvaziestetického či pseudoprestižního pohledu mohou „zdobit“. Př́padná „ornamentální funkce kodexů je však druhořadá; rozhodují obsahová hlediska. K některým z nich se vyjadřuji. ${ }^{3}$

\section{Pryč od direktivního hospodářského práva?}

\section{Svoboda neni vlastnè nikedy v nebezpeři, ovšem jen chápeme-li ji supercynicky jakožto ,poznanou nutnost".}

Od katedry se počátkem 90. let minulého století právem očekávalo, že se ujme odborného rozvoje a výuky obchodního práva poté, co byl zrušen hospodářský zákoník, který byl i přes svoje podstatné novelizace v závěrečném období své působnosti neodstranitelně geneticky zatížen a bránil by rozvoji skutečného podnikání a obchodu na bázi tržní ekonomiky.

Občanský zákoník ${ }^{4}$ se totiž v majetkové oblasti vztahoval jen na právní vztahy občanů navzájem a na vztahy občanů a tzv. socialistických organizací, ovšem jen při uspokojování osobních potřeb občanů. Nebyl vůbec uzpůsoben (a ani zamýšlen) k regulaci vztahů podnikatelských a obchodních a žádná specifika nestanovil ani pro ty prípady, kdy byl výjimečně používán na vztahy nepatrného počtu soukromě hospodařících občanů k organizacím tzv. socialistického sektoru, popř. občas na vztahy tuzemských „nesocialistických“ organizací k občanům a k organizacím „socialistickým“.

Hospodářský zákoník ${ }^{5}$ byl systematickým výrazem hybridní koncepce tzv. „diagonálních vztahư“, které měly propojit řídící osu (mocenské zájmy prosazované centrálně) s dílčími

3 Navazuji na dřivější dobové úvahy: BEJČEK, J. The New Commercial Code of the Czech Republic. The John Marshall Law Review, Chicago: The John Marshall Law School, 1997, roč. 1997, č. 3, s. 699-723; BEJČEK, J. Účelovost nebo účelnost didaktické parcelace závazkového práva? Časopis pro právni vědu a praxi, 2012, č. 4, s. 319-325. Dostupné z: https://journals.muni.cz/cpvp/article/view/5806; BEJČEK, J. Obchodní a hospodářské právo v době „postkodexové“. Obchodněprávni revue, 2014, č. 7-8, s. 204-212; PELIKÁNOVÁ, I. Koncepce obchodního práva v nové soukromoprávní kodifikaci. Casopis pro právni védu a praxi, 2015, č. 1, s. 39-49. Dostupné z: https://journals.muni.cz/cpvp/article/ view/5355. Protože tento žánrově hybridní příležitostný příspěvek nemá ambice být původní odbornou prací, tak některé svoje dřívější myšlenky obsažené v pracích sub pozn. 3 znovu uvádím a shrnuji, resp. parafrázuji a doplňuji, aniž čtenáře obtěžuji detailními sebecitacemi.

4 Zákon č. 40/1964 Sb.

5 Zákon č. 109/1964 Sb. 
hospodářskými zájmy a zbytkovou iniciativou ekonomicky neplnoprávných jednotek (socialistických podniků a jejich sdruženî) v rámci centrálního systému řízení.

Ona údajná „diagonalita“ či „emulznost“ hospodářskoprávní metody regulace ${ }^{6}$ byla však spíše eufemismem, nebot' ve skutečnosti šlo o vertikální metodu regulace s velmi omezenými výjimkami zdánlivé samostatnosti a odpovědnosti ekonomických jednotek, které byly v důsledku závislé a ovladatelné administrativními nástroji z centra, a to od fáze jejich vzniku, přes provádění hospodářské činnosti, až po jejich eventuální zrušení a zánik (či i jejich nucenou záchranu kvưli „,celospolečenskému zájmu“, navzdory třeba i mizerným hospodářským výsledkům, které se pomocí zpětné změny plánu ,zhojily“). Kromě toho i řada nominálně zachovaných právních institutů nemohla v reálném ekonomickém prostředí tzv. reálného socialismu fakticky přežít a zůstala prázdnými pojmy. Zákoník mezinárodního obchodu ${ }^{8}$ musel být v 60. letech přijat v zájmu rozvoje mezinárodní hospodářské spolupráce (právních vztahů s cizím prvkem), nebot' charakter právní úpravy v hospodářském zákoníku (koncipovaném pro potřeby centrálně řízené plánované ekonomiky s širokými možnostmi zásahů řídících orgánů do závazkových vztahů) neposkytoval zahraničním partnerům nutný a v tržních ekonomikách obvyklý standard smluvní volnosti a právní jistoty. Bez legislativně technicky vysoce kvalitních předpisů pro vztahy s cizím prvkem, založených na klasických principech soukromého práva, by náš právní řád odrazoval zahraniční partnery od jakékoliv hospodářské spolupráce.

Hospodářské právo bylo typickým reprezentantem těch odvětví, která se tradičně označují jako veřejnoprávní, a to ve smyslu zájmové i mocenské teorie veřejného práva. Umožňovalo, aby se v různých podmínkách prosazovala jedna vưle, a to vưle ekonomického a politického centra, vyjádřená v plánovacích aktech a v důsledku jištěná mimosoudním rozhodováním hospodářských sporů mimosoudní soustavou (nikoliv nezávislé) státní arbitráže, jež byla mj. i orgánem hospodářského řízení podle odchylek. Tržně konformní obchodní právo zrodivší se v podobě obchodního zákoníku v roce 1991 mělo očividně zásadně odlišnou povahu a cíle.

6 Srov. HAJN, P. Hospodář́séé právo. Brno: Univerzita J. E. Purkyně, 1974, s. 11-12.

7 Tak např̀. karikatura „hospodářské soutěže“ v direktivně plánované a zmonopolizované ekonomice. Pod tradičními názvy se mohl skrývat podstatně zdeformovaný obsah (např. „,hospodářská smlouva“ měla velmi daleko k tradičnímu soukromoprávnímu smluvnímu konceptu).

8 Zákon č. 101/1963 Sb.

9 V našem právním řádu trojkolejnost kodexové právní úpravy majetkových vztahů přetrvala až do 1. ledna 1992, kdy nabyl mj. účinnosti obchodní zákoník a novela „,socialistického“ občanského zákoníku a kdy byl zrušen zákoník mezinárodního obchodu. Odlišné kodexové právní režimy pro různé druhy vztahů a pro různé subjekty byly přitom samožrejmě přenášeny i do jiných souvisejících zákonů i podzákonných předpisů. Existence tř́ v zásadě nezávislých a principiálně odlišných kodexů, které stanovovaly různá „,pravidla hry“ v ekonomice, byla objektivně překážkou v procesu transformace ekonomiky a bránila rychlejšímu a přirozenému formování tržních vztahů. Různé podmínky pro soutěžitele neumožňovaly rozvoj základního hybného faktoru ekonomiky s převahou tržních autoregulačních prvků - totiž volné konkurence a poctivé soutěže. 
Náplň předmětu „obchodní právo“ jsme postupně upřesňovali - bylo nám jasné, že nemưžeme učit jen „obchodní zákoník“, ale že „,pod naše křídla“ bude patřit i leccos z dřívějš́iho předmětu práva hospodářského, které nezmizí z povrchu zemského jen proto, že byl zrušen hospodářský zákoník.

Obchodní právo v širším smyslu (ke kterémužto funkčnímu pojetí jsme se spolu s převažující částí českých komercialistů hlásili a hlásíme) zahrnuje soukromoprávní i veřejnoprávní úpravu. Podobně jako je „zmatením jazykư“ zatížen pojem „obchodní právo“, týká se to i práva hospodářského a je vždy nutno z kontextu zjistit, kde vlastně jsou hranice oboru takto pojmenovaného. I hospodářské právo se někdy rozlišuje na „hospodářské právo soukromé“ (pod nímž se rozumí to, co my označujeme za právo obchodní) a na „hospodářské právo“ (tzv. „prostéc), pod nímž se skrývá jen veřejnoprávní regulace ekonomiky a podnikání. ${ }^{10}$

Pojem i věcný obsah hospodářského práva se liší podle toho, zda je používán v kontextu tržní ekonomiky, nebo zda se hovoří o tzv. hospodářském právu reálného socialismu. ${ }^{11}$ $\mathrm{V}$ prvém př́padě jde o veřejnoprávní úpravu zásahů státu do podnikání a obchodu, která funguje vedle klasických soukromoprávních úprav civilistických a obchodněprávních. Ve druhém případě se jedná o dominantní systém centrálního řízení přetvořený do veřejnoprávních norem, které neponechávají téměř žádný prostor smluvní autonomii a nezávislosti subjektů. Cílem je prosazení tzv. celospolečenských zájmů a hledisek za současného potlačení soukromých zájmů - pokud jejich sledování je vůbec připuštěno, pak jsou jen ve služebné roli vưči ,zájmům vyšším“ a v prípadě konfliktu jim zájmy soukromé musejí ustoupit. Hospodářskému právu v oné hybridní podobě jsme se na katedře věnovali od samotného znovuobnovení fakulty. Přitom vznikaly i některé teoretické práce zabývající se společenskými funkcemi hospodářského práva, vztahem hospodářského rozhodování a hospodár̆ského práva včetně regulace rizika, podstatou a funkcemi právní odpovědnosti apod., jejichž prrínos je nadčasový a není vázán jen na tehdejší právně politické prostředí.

10 Tak v Polsku - srov. KATNER, W. J. (ed.). Prawo cywilne $i$ handlowe w zarysie. 4. vyd. Warszawa: Wolters Kluwer Polska, 2011, s. 27 a násl., s. 30 a násl.

11 Dnes má dělení na hospodářské právo „tržni““ a hospodářské právo „plánovaci““ (resp. socialistické) již jen historický význam.

Je to však důležité hlavně pro ty, kteří se (spíše z předpojatých ideologických pozic) tváří štítivě na slovní spojení „hospodářské právo“, jako by ono automaticky implikovalo ten obsah, který jsme znali před r. 1989.

Že tomu tak není, dokazuje zejména německé, francouzské, polské nebo slovenské pojetí oboru hospodářského práva. Je však zbytečné dále rozmělňovat pojem hospodářského práva, jenž se vesměs chápe jako součást tzv. práva veřejného, zaváděním pojmu hospodářského práva $\mathrm{v}$ tzv. širším smyslu (á la MALOVSKÝ-WENIG, A. Príručka obchodníbo práva. Praha: Československý kompas, 1947) a jeho následným dělením na hospodářské právo soukromé (obchodnî) a na hospodářské právo veřejné. Tak široké klasifikační kritérium totiž postrádá metodologický i praktický smysl. Podobným nesmyslným způsobem by se totiž dala za součást občanského práva „, širokém smyslu“ označit jakákoliv právní úprava, která se týká právního postavení a života občanů, a patřilo by tam tedy i právo správní, včetně části „,práva daňového“, právo trestní, mezinárodní soukromé apod. 
Velký rozptyl pojetí hospodářského práva můžeme pozorovat v posttotalitních zemích s tradicí tzv. socialistického hospodářského práva. Bez bližšího zkoumání konkrétního kontextu je nemožné se dohadovat, co vše se vlastně pod oním pojmem skrývá - zda jde jen o označení historicky pominuvší části právní regulace z dob socialismu, či zda jde o určitou veřejnoprávní část obchodního práva v širokém slova smyslu, či o úpravu jen administrativněprávních ingerencí státu do ekonomiky (v klasickém pojetí západních zemí, které zasahují do veřejné ekonomiky prostředky a formami správního práva, z něhož se právě pro tyto účely vyčleňuje tzv. právo hospodářské jako jeho odnož).

Hospodářské právo „západního střihu“ se nedá vzhledem k úplně odlišným podmínkám a rozsahu působnosti a použitým metodám se socialistickým hospodářským právem srovnávat. Spojuje je sice slovo „hospodářské“ a veřejnoprávní metoda regulace, ale hospodářství v tržních ekonomikách nebylo na rozdíl od socialistických zemí jen veřejné a nosný byl soukromý sektor se soukromoprávní regulací občanskoprávní a obchodněprávní. Ta se zejména u nás po přijetí hospodářského zákoníku v r. 1964 nepoužila ani podpůrnè.

Předlistopadové hospodářské právo si tak v oblasti obchodu a „podnikáni““ přisvojilo to, co bylo na Západě předmětem práva obchodního, přičemž se ovšem téměř vše ,,soukromoprávní “ potlačilo. $\mathrm{V}$ podstatě $\mathrm{z}$ konvenčních a praktických důvodů se z pojmu hospodářského práva ( $v$ onom nejširším ,megasmyslu“) tradicionalisticky vyčleňuje právo pracovní, finanční, správní1 ${ }^{12}$ apod., i když se na druhé straně někdy (vlastní a většinově sotva sporný) obsah hospodářského práva (veřejnoprávní úprava vztahů s podnikáním souvisejících) pokládá za součást práva obchodního, čímž by se ovšem pojem hospodářského práva vyprázdnil úplně. ${ }^{13}$

Mnohovýznamovost, neujasněnost a terminologické zmatení pronásledují hospodářské právo i na západ od nás a v podstatě se na všeobecnou definiční shodu a akceptaci přesného členění rezignuje. ${ }^{14}$ Každý, kdo se hospodářským právem zabývá, si tak vlastně může vytyčit jeho hranice $\mathrm{k}$ obrazu svému a rovněž tak překryvy a vymezení ve vztahu k právu soukromému, veřejnému, podnikatelskému, správnímu, správnímu trestnímu apod. podléhají subjektivismu.

Současné katedrové výukové programy se obsahově nedávají mást předpojatostmi a reminiscencemi. Obsah toho, co se v předmětu „hospodářské právo“v zemích s tržní ekonomikou běžně vyučuje, předáváme studentům nadále, byt' pod „politicky korektnějším“ a neprríznivých asociací zbaveným názvem ,právo obchodní“. Důvodem je, že výuka regulatoriky podnikání je pro výbavu absolventů praktická a nezbytná. Pokud by nebyla

12 Srov. HUSÁR, J. Právna regulácia ingerencie verejnej moci do podnikania (Hospodársko právo - náčrt teórie a systému). Košice: Equilibria, 2007, s. 24 a násl.

13 Srov. PELIKÁNOVÁ, I. a kol. Obchodní právo 1. 2. vyd. Praha: Wolters Kluwer, 2010, s. 136.

14 Srov. RINCK, G. a E. SCHWARK. Wirtschaftsrecht. Köln-Berlin-Bonn-München: Carl Heymanns Verlag, 1986, s. 9. 
ona (veřejnoprávní) regulatorní část obchodního práva rozvíjena systematicky, mohlo by se stát, že právníci budou narážet na veřejnoprávní limity podnikání až „za pochodu“ v praxi, protože na škole to učitelé považovali za starost „,ťch z jiného oboru“. To by šlo k tíži absolventů (a svědomí nás učitelů) a zejména na úkor kvality právní služby.

\title{
2 „Kodexové obdobi““ obchodního práva
}

\author{
Zlatý vzešel napotom věk, kedy zákona, ${ }^{15}$ soudce \\ nike nebyl prost, neb nectil sám od sebe vérnost a právo... ${ }^{16}$
}

Na pomyslném výsluní zájmu a významu se obchodní právo ocitlo ve dvacetiletí následujícím po přijetí obchodního zákoníku v roce 1991. Obchodní zákoník byl jedním z nástrojů rušících falešnou monolitičnost „reálně socialistického“ práva a jeho hypertrofovanou vertikální (regulatorní linii). Projevilo se to zejména v oblasti vztahů závazkových, po sjednocení jejichž úpravy se volalo již dlouho. ${ }^{17}$ Svěrací kazajka administrativně pojatého hospodářského práva se uvolnila ${ }^{18}$ a návrat klasického soukromoprávního ovzduší přirozeně zapůsobil regeneračně i na strukturu a obsah výuky.

Závazkové vztahy se staly především smluvními v pravém slova smyslu, který hospodár̆ský zákoník masivně popíral. Ty se velmi liberalizovaly, byla obnovena široká smluvní volnost, byla odstraněna zákonná kontraktační povinnost. Zavedla se zásadní dispozitivnost právní úpravy obchodních závazkových vztahư ${ }^{19}$ (na rozdíl od vesměs kogentní právní úpravy $\mathrm{v}$ hospodářském zákoníku a $\mathrm{v}$ podzákonných prováděcích předpisech, která neumožňovala stranám odchýlit se od právních řešení vyhovujících potřebám centrálně a direktivně ř́izené ekonomiky). V souladu se zásadou smluvní svobody a autonomie vůle se prosadila zásadní neformálnost uzavírání smluv (na rozdíl od zásadní

15 Rozuměno „obchodního“...

16 Publius Ovidius Naso, jehož hexametr „Čtvero věkư“ z Proměn tu přidrzle a ironicky parafrázuji, již prominout nemůže, tak snad tedy aspoň čtenář ano. Původní text znectěné strofy ( $\mathrm{v}$ překladu Ferdinanda Stiebitze) zní:

Zlatý vzešel nejprve věke, kdy zákona, soudce

člověke byl prost a od sebe sám ctil vérnost a právo.

Nebylo trestu ni strachu, a broziviá slova se nećtla,

vyrytá v kov, a prosici dav se nemusel báti

soudcových üst: ač nemèli obhájce, beapečni byli.

17 K tomu srov. např. KOPÁČ, L. Věc: Obchodní zákoník. Hospodářské noviny, 1991, č. 37, s. 8; ELIÁŠ, K. Téma k diskusi: Obchodní zákoník. Právník, 1992, č. 6, s. 475-492; BEJČEK, J. K působnosti obchodního zákoníku v závazkových vztazích. Právník, 1993, č. 2, s. 173-183.

18 Z dnešního pohledu asi až prúliš - viz často kritizovanou absenci veřejnoprávní regulace při privatizaci (tunelovánî) v „divokých devadesátkách“. Srov. BEJČEK, J. Privatizační projekty: Rozhodování bez pravidel? Hospodárské noviny, 1991, č. 26, s. 14.

19 Byt' nedostatečně přesně mj. ve vztahu k úpravě v občanském zákoníku. Srov. např. diskusi k charakteru právní regulace sazby úroků z prodlení a poplatků z prodlení podle Nařízení vlády č. 142/1994 Sb. - blíže BEJČEK, J. „Povaha ustanoveni““ o úrocích z prodlení. Právní roð̧hledy, 2006, č. 11, s. 406 a násl. 
písemnosti smluv hospodářskoprávních). Sjednotila se právní úprava pravidel chování pro tuzemské účastníky obchodních vztahů a byly odstraněny protisoutěžní diskriminačně-preferenční rozdíly na základě formálního statusu subjektů. Implementovala se ustanovení řady mezinárodních obchodněprávních úmluv a zvyklostí do obchodního zákoníku, což mj. ulehčilo adaptaci našich podnikatelů na standardy obvyklé v zahraničí. Zmizela dřívější relativní izolovanost a vzájemná nezávislost právních úprav hospodářských vztahů s odchylným režimem, který závisel na charakteru subjektů právního vztahu - obchodní zákoník se stal integrální součástí soustavy soukromoprávních předpisů; navíc v nouzi dané zejména neexistencí sjednocujícího civilního kodexu upravil řadu veřejnoprávních i soukromoprávních otázek s platností pro celý právní rád, a to zčásti i pro nepodnikatele. Stal se tak i nositelem vývoje progresivních tendencí v řadě oblastí soukromého práva, kteroužto roli by normálně měl mít především zákoník občanský. ${ }^{20}$ Důležitost obchodního práva ve výuce a zkoušení plynula mj. právě z této skutečnosti; instituty a řešení zprostředkované obchodním zákoníkem poskytovaly nezbytnou část odborné průpravy o tom, co je to vlastně soukromé právo - občanský zákoník ve své tehdejší podobě měl v tomto směru značnou nevýhodu.

Zrodila se však naopak velmi složitá a dřive nezažitá problematika vzájemných vztahů občanského a obchodního zákoníku, jež snížila přehlednost a jednoznačnost právní úpravy a s tím související právní jistotu. Kodifikace obchodního práva měla mimořádný depurační efekt. ${ }^{21}$ To se opět projevilo ve výuce, která se osvobodila od apologetiky některých podzákonných účelových předpisů (nezřídka stěží pochopitelných pro učitele, natož pak pro studenty ${ }^{22}$ ) a mohla se namísto toho věnovat třeba rozvoji umění opravdové kontraktace.

Přijetí obchodního zákoníku i přes jeho chyby napomohlo kromě výše uvedených důsledků i přechodu (u starších právníků návratu) k tradičnímu způsobu právního myšlení, $\mathrm{k}$ pochopení a $\mathrm{k}$ praktickému používání tradičních (a přitom u nás řadě právníků málo známých) soukromoprávních institutů a postupů a k vytváření praktických dovedností prri tvořivém výkladu a uplatňování práva, k němuž hospodářský zákoník poskytoval jen velmi omezený prostor. Určitý ,adaptační šok“ utrpěli samozřejmě i naši učitelé, kteří však byli velmi záhy schopni zprostředkovat nejen studentům, ale i praktikům řadu

20 To se ostatně projevilo i na novém občanském zákoníku č. 89/2012 Sb., který zpětně čerpal podstatnou část svých konstrukcí z praxí prověřeného a dlouho judikovaného zákoníku obchodního.

21 Obchodní zákoník přinesl sice téměř 800 nových paragrafů, ale současně zrušil přes 80 právních předpisů, a to většinou podzákonných, velmi podrobných a s převahou kogentních právních norem. Tím velmi uvolnil rozhodovací prostor podnikatelům a v souladu s principy právního státu přesunul těžiště právní úpravy na úroveň zákona vyjadřujícího skutečně obecný zájem.

22 Jako např. pověstná vyhláška Státní plánovací komise a Státní arbitráže Československé socialistické republiky č. 48/1980 Sb., o hmotném bilancování a projednávání dodavatelsko-odběratelských vztahů v plánovacím procesu, z níž se „točila hlava“ i dlouholetým právním praktikům externě působícím na katedře. 
nových poznatků a souvislostí podle platné úpravy. Naši pedagogové rozvijeli s využitím četných zahraničních kontaktů doktrínu obchodního práva velmi činorodě.

Status oboru obchodního práva jako navýsost potřebné a praktické disciplíny, která navíc díky obchodnímu zákoníku otevírala v řadě směrů „okno“ do klasického soukromého práva, byl nesporný. Projevovalo se to i tím, že obchodní právo bylo povinnou součástí státní závěrečné zkoušky - mohla tu, pravda, působit i tradice a rigidita státnic, u nichž obchodní právo prostě jen nahradilo dříve povinné právo hospodářské.

\section{Pryč od obchodního (postkodexového) práva?}

\section{Clověke, který má rád uzeniny a dodř̌uje zákony, by nemèl být u toho, když se tyto věci dělají.}

Vztahový problém občanského zákoníku přijatého v roce 1964 a zákoníku obchodního odstranila samozřejmě rekodifikace soukromého práva v roce 2012. Nové problémy však vznikly (a v procesu aplikace a realizace práva se nepochybně další objevî) mezi novým občanským zákoníkem a zákonem o obchodních korporacích. Navíc každý z těchto dvou předpisů obsahuje sám o sobě řadu vlastních vnitřních nejasností v počtu určitě ne menším, než vyplýval ze vztahových nejasností za účinnosti novelizovaného tzv. socialistického občanského zákoníku a zákoníku obchodního. Nové předpisy si s bohatou zásobou vlastních vnitřních nejasností určitě vystačí po dlouhá léta, než budou odstraněny novelizacemi nebo výkladem (což je etapa, kterou dřívější předpisy již měly z velké části za sebou). K výčtu a natož rozboru řady sporných koncepčních i jednotlivých ustanovení a vyložených chyb v rozsáhlém občanském zákoníku není při této př́ležitosti prostor. Týká se to i transparentnosti legislativního procesu a zpětné vazby teorie i praxe na jeho výsledek.

Odborná i výuková činnost katedry se v tomto stále trvajícím období zaměřuje zejména na koncepční i výkladové problémy obsažené v nových úpravách. Obchodní právo jako odborná právní disciplína ani jako pedagogický obor samozrejmě nezmizelo proto, že byl zrušen obchodní zákoník. Subjektově a věcně podmíněné zvláštnosti obchodních vztahů se tímto aktem nesetřely, ale naopak se na pozadí obecné úpravy a v jejím rámci nesporně, jasně a jednoznačně odlišily. Metaforicky (a útěšně pro staromilce) to lze vyjádřit i tak, že implicitní a virtuální „obchodní zákoník“ mohou při troše představivosti vidět stále; jen je zanořen do platného obecného soukromoprávního občanského zákoníku.

Přiznávat strukturotvorný (odvětvově právnî) význam kodifikaci (analogicky strukturoborný účinek dekodifikaci) je voluntaristické a subjektivistické, přinejmenším v naší konkrétní situaci, kdy se jiná (a zásadnějšî) kritéria tzv. odvětvové samostatnosti obchodního práva (předmět regulace, metoda úpravy, specifické instituty) nezměnila. 
O odvětvovou samostatnost ostatně vůbec nejde. $\mathrm{O}$ (ne)smysluplnosti diskusí o odvětvové samostatnosti právních odvětví, která (asi pro nedostatek důležitějších nebo přípustných problémů právní teorie) planula ještě před několika dekádami, svědčí, že tiše odumřely a vlastně dnes nikoho nezajímají. Nemá proto smysl v nich pokračovat. ${ }^{23}$

Obchodní právo totiž bez ohledu na tento kvaziatribut existuje a pěstuje se jako speciální disciplína nejen v zemích s dualistickou koncepcí, součástí jejichž právního řádu jsou i zvláštní obchodní zákoníky (nap̌r. Německo, Rakousko, Francie), ale i v zemích bez takové úpravy (např̀. Itálie, Švýcarsko ${ }^{24}$ ). Jakékoliv pseudoprestižní a poziční předsudky o tzv. odvětvové samostatnosti jsou málo významné z hlediska praktického fungování a dopadu právní úpravy, jakož i z hlediska pedagogického či vědeckého, a proto se jimi ani nezabýváme. Obchodní právo tedy obsahově zůstává tím, čím bylo dříve, bez ohledu na ztrátu „kodifikační výhody.“

Svoje „,teritorium“ si každý úsek doktríny i legislativy či pedagogického zprostředkování poznatků vymezuje především svým reálným významem a kvalitou, a nikoliv autoritativním „výnosem“ o odvětvové samostatnosti či nesamostatnosti. Praktický význam může diskuse mít z hlediska metodologického, z hlediska klasifikace a struktury oborových vědních a pedagogických disciplín; problémy by mohly být v souvisejících akreditačních procesech, v dělbě výuky a zejména v bezmezerovitém pokrytí tzv. soukromého práva jak doktrinálně, tak pedagogicky.

Nemáme problém nejen s vymezením své působnosti, ale ani s potřebností a významem disciplíny, již pěstujeme. Pojem obchodního práva se vlastně vymezuje svým přívlastkem sám, nicméně jen formou tautologického odkazu na pojem „obchod“, či „obchodní“. 25 To nemusí být nutně chápáno čistě pozitivisticky (ve smyslu „co je upraveno předpisy zvanými obchodněprávníc), ale lze připustit i flexibilní (a expanzivnî) funkční pojetí - za „obchodněprávní“ se dají totiž naopak považovat veškeré instituty související s obchodem, at' už jsou upraveny kdekoliv.

Obchody tradičně chápeme (a i studujícím zprostředkováváme) ve dvou smyslech: v užším, stavovském (subjektivním), jako právem regulovaný styk příslušníků stavu obchodnického, tedy těch, kterým právo přiznává status obchodníka (podnikatele). Druhé (objektivnî) pojetí zdůrazňuje tzv. obchody, jakožto typické akty oběhu statků, ${ }^{26}$ k nimž dochází bez ohledu na osobní podnikatelský či nepodnikatelský status účastníků. Jde opět o záležitost spíše konvenční: dohodnout se, jak nazveme zvláštní druh práva (zásadně soukromého) upravujícího obchodní činnost provozovanou dlouhodobě

\footnotetext{
23 Shodně PELIKÁNOVÁ, op. cit., s. 39.

24 Srov. CANARIS, C.-W. Handelsrecht. 24. vyd. München: C. H. Beck, 2006, s. 5.

25 Tak RANDA, A. Soukromé obchodní právo rakouské. Praha: Nakl. J. Otto, 1908, s. 15.

26 Srov. např. již MALOVSKÝ-WENIG, op. cit., s. 2.
} 
na profesionálním základě. ${ }^{27}$ Proto za obchody pokládáme (a můžeme si činit nárok na jejich pedagogickou garanci) i typické „obchodní“ smlouvy, jako jsou zejm. smlouva zasilatelská, komise, bankovní obchody, přepravní smlouvy, pojištění, pacht (především obchodního závodu), podnikatelský nájem, obchodní zastoupení, zprostředkování (z podstatné části), kontrolní činnost, tichá společnost aj., upravené dnes v zákoníku občanském. $^{28}$

Studenti si mají uvědomit a procvičit znalost, že obchodní právo spočívá na základně všeobecného práva občanského a doplňuje je zvláštními úpravami, jež se vztahují na kvalifikovaný okruh subjektů - podnikatele; přitom tyto předpisy mají sloužit ulehčení a urychlení obchodního styku i za cenu snížené ochrany účastníků tohoto styku; na druhé straně je odpovědnost podnikatelů za sebe samotné vyšší nežli ve všeobecném občanskoprávním styku (soukromé právo spotřebitelské). ${ }^{29}$ To vyžaduje dobrou metodologickou koordinaci a posloupnost výuky oborů „všeobecného“ občanského práva a „zvláštního obchodního“ občanského práva. O tu se od počátku snažíme a chceme v ní pokročit ještě dále; v současnosti mj. zvažujeme společnou výuku práva závazkového. ${ }^{30}$

Jednotnosti soukromého práva ovšem neodpovídá (a profilu absolventa a jeho pripravenosti pro praxi neprospívá) postavení obchodního práva jako jen jedné z ráadových volitelných disciplín u státních závěrečných zkoušek $v$ jedné řadě s obory ne vždy srovnatelnými rozsahem, náročností a svou potřebností pro profesionální výbavu absolventa. Nemám sice „tvrdá data“, ale jsem jako dlouholetý bývalý akademický funkcionář, učitel i právní praktik přesvědčen, že běžný absolvent se s obchodním právem (v širokém slova smyslu zahrnujícím i veřejnoprávní regulatorní rámec podnikánî) potkává významně častěji nežli u některých předmětů dnes „typicky státnicových“. Pokud zůstane systém

27 Podobně KREJCI, H. Grundrisß des Handelsrechts. Wien: Manz Verlag, 1995, s. 3-5.

28 Dělba práce s katedrou občanského práva je ovšem občas oportunní a závisí na tradici a katedrové př́islušnosti a odborné afinitě toho či onoho specialisty. To lze ovšem změnit.

29 Tak BÜLOV, P. Handelsrecht. 4. vyd., Heidelberg: C. F. Müller, 2001, s. 1-3.

30 Právě v této oblasti vznikla totiž jako vedlejší účinek nekoncepční dvoukolejnosti a roztříštěnosti úpravy obligačního práva jakási „metavěda“ o obchodních obligacích, která se snažila pro účely aplikace práva a jeho srozumitelné výuky „dodávat“ ex post teoretické „pojivo“ do úpravy, v jejichž základech v řadě př́padů prostě chybělo. Mám však dlouhodobě za empiricky ověřený předpoklad, že ani ev. opakování látky probrané $\mathrm{v}$ jiném předmětu z poněkud jiného hlediska není něčím, čeho bychom se měli apriorně obávat (repetitio - mater studiorum) a čemu bychom se měli v učebních plánech panicky vyhýbat. Naopak pokládám dílčí (nikoliv plošné!) pedagogické překrývání v hraničních oblastech za výhodu pro studenty, jež je vede ke komplexnějšímu pochopení právní úpravy, resp. přinejmenším alespoň k upevnění její znalosti. Je věcí konvence, do jaké hloubky a v jakém rozsahu by se těmi či oněmi instituty zabývaly katedry občanského práva nebo obchodního práva, resp. by šlo o „vnitroústavni“ dělbu práce u šíreji založených ústavi̊ či kateder práva soukromého. Svoji roli sehraje také personální vybavení jednotlivých pracovišt', výzkumné zaměření jednotlivých učitelů a jejich praktická profesní zkušenost atp. At’ prostě určité oblasti učí ten, kdo je v nich nejlepší a nejdál. 
státnic zachován jako dnes, zaslouží si obchodní právo místo srovnatelné s právem občanským (nebo má být zkoušeno spolu s ním), trestním či správním. ${ }^{31}$

\section{Trochu akademicko-právnické spirituality a (de)morality}

„Sejde-li se organizovanè vice právníkủ na nèjaké vy šsí úrovni, nemluvi o normách, nýbrž. o tradici, hodnotách, spravedlnosti, férovosti, rovnosti, nezávislosti, kolegialité, nestrannosti a o oddanosti tèmto nejasným pojmuim a o lásce k právu a o svém poslání. “32

Troufám si připojit „submotto“: jsou-li to navíc učitelé, přidává se k těmto vznešeným tématům nezřídka obligátní lamentace nad nízkou náročností studia, nad úrovní přijímaných studentů i absolventů, nad potřebným poměrem obecné mimoprávní i právní vzdělanosti a specializovaných praktických dovedností apod. Někteří z nás rezignujî $\mathrm{a}$ „doklepávaji“ to poklidně $\mathrm{v}$ „,nezměnitelném“ systému, jiní kritice aspoň souhlasně a přizpůsobivě přibrblávají a přitakají při obědových seancích či náhodných kuloárních setkáních a kupují si tak pocit, že jim to není lhostejné a že to „už také dlouho říkají“; jinî se aspoň občas ozývají na různých fórech, nebo tvrdošíjně lpí na standardech i za cenu jistého sociálního vyloučení - mají-li aspoň nějaké rozhodovací pravomoci, doutná právě $\mathrm{v}$ nich alespoň jiskřička naděje, že není vše ztraceno. ${ }^{33}$

„Demokratizace vzdělání“ bylo nejen líbivé heslo tzv. reálného socialismu, nad kterým bychom se dnes mohli jen povýšenecky a „historicky poučeně“ ušklíbat - mohli bychom se totiž dopustit faux pas úsměšky nad něčím, k čemu sklouzli i na „Západě“. Ona demokratizace umožnila totiž mnoha lidem z „obyčejných poměrư“, kteří by na to jinak z ekonomických a sociálních důvodů nemohli ani pomyslet, vystudovat vysokou školu, a to nezrrídka s vynikajícími výsledky. ${ }^{34}$

31 Postavení oboru jakožto „olympijské disciplíny“ samozřejmě zpětně ovlivňuje i zájem studentů a jejich motivaci a tím i úroveň jejich znalostí a dovedností - právě ty obchodněprávní přitom pokládám za nezbytnou a formativní součást jejich profesionální výbavy. Proto by měla být testována na stejné úrovni jako u stávajících klíčových předmětů. Tyto nároky se přitom bez přetržky (nikoliv kupodivu) prosazují na pražské právnické fakultě, k níž se vztahujeme jako k referenčnímu bodu.

Moje opakované podněty jakožto vedoucího katedry, požadující státnicové zrovnoprávnění obchodního práva, zůstávají (bohužel již několik let) zatím stále oslyšeny.

Tento problém souvisí s funkcí zkoušky (maturitní, přijímací, postupové, státnî) jakožto standardu požadované úrovně, který by se každému méně schopnému či pracovitému studentovi neměl přizpůsobovat „na míru“ (třeba pod záminkou specializace). Tyto otázky mj. glosuji v následující kapitolce.

32 Srov. ČERMÁK, K. Od právníkovy introspekce k právnické sebereflexi. Bulletin advokacie, 2007, č. 10 , s. 60.

33 Tento příspěvek je formou blahopřání mé domovské fakultě k narozeninám. Myslím, že není lepší dárek od srdce než upřímnost. Proto se jí tu vědomě dopouštím, byt’ leckde na úkor suché ,akademické“ vznešenosti a bezkrevné uhlazenosti a diplomatičnosti formulací.

34 Pozdější ekonomická homogenizace společnosti oslabila naléhavost této potřeby; ale až do normalizace se někteří lidé středního věku dostávali ke vzdělání, k němuž i desetiletí po válce neměli přiležitost; srov. rozšířené studium při zaměstnání („dálkaři“‘) pod heslem „druhé šance“, která byla mnohdy vlastně šancí prvou. Úroveň dálkařů byla v průměru (čest výjimkám) výrazně nižší, ač dosáhli formálně stejné kvalifikace jako denní studenti. 
Jako většina dobře myšlených vznešených ideji ${ }^{35}$ byla i tato myšlenka napadena virem vulgarizace a oportunismu. Za „demokratizaci“ se občas skrylo odstranění nebo trivializace překážek vstupu i výstupu tak, aby se garantovala nejen stejná př́ležitost, ale aby se zaručil i výsledek. Pod jejím pláštíkem se v minulosti ovšem zhusta dostalo (díky systému sociálně inženýrských a třídních kvót) formálního titulu (nekorespondujícího s odpovídajícím vzděláním) i lidem, kteří by jinak na tuto metu také nemohli ani pomyslet, ale kvưli absenci pohříchu osobnostních intelektuálních a charakterově-volních kvalit. Místo předválečného zaměření na intelektuálně střední a horní vrstvu mládeže se v současnosti v celé Evropě vyšší vzdělávání orientuje spíše na intelektuálně střední a nižší vrstvu, což střední vrstvu stahuje dolů, zatímco dříve aspirovala na vzestup. Chybí údajně širší univerzální vzdělanostní základ, většina našich maturantů je ,duševně zanedbaná“ a ani z těch nejnadanějších se nestávají vzdělanci, ale nanejvýš geniální fachidioti; navíc na školách neuvěritelně klesá kázeň. ${ }^{36}$

Bohužel nemám k dispozici analytické údaje, abych se mohl odvážit hodnocení, zda naší vzdělanosti (té skutečné, nikoliv té „měřené“ procenty nositelů maturitních vysvědčení a leckdy pofidérních titulů z obskurních škol) uškodila více „socialistická demokratizace školstvi“،, nebo statistické zvyšování formálni úrovně vzdělanosti našeho národa (snížením úrovně skutečné vzdělanosti) ve snaze vyrovnat se v tomto parametru vyspělejším zemím. ${ }^{37}$ Jako by formální znaky vzdělání mohly nahradit obsah. ${ }^{38}$

Jsme jako fakulta vysoké školy na pomyslném vrcholu pyramidy, kvalita jejíchž nižších stupňů rozhoduje o tom, na čem můžeme stavět my. Problémy úrovně středních škol, standardu maturit, ale zprostředkovaně i škol základních se nás tedy také dotýkají. Nebo se také můžeme tvárít, že nás nezajímají a nastavit na vstupu jen test všeobecných studijních předpokladů, přijímat ty, již mu nejlépe vyhoví a netrápit se tím, že z percentilu 90 a více nutného dř́ve pro přijetí na fakultu klesáme až někam $\mathrm{k}$ percentilu kolem padesáti. Navíc ty kýžené studijní předpoklady jsou formálně abstraktní, netestované zpětnou vazbou. V šeobecně bystrý student ještě nemusí být dobrým studentem práv, pokud nemá jistou sumu znalostí a dovedností nabytých ne vrozenou kombinatorickou bystrostí a pohotovostí, ale dlouhodobějším studiem, resp. výcvikem. Všeobecnou inteligenci strukturuje každý obor jinak, resp. toto strukturování je třeba testovat již na vstupu;

35 Aspoň já v ty dobré úmysly v tomto př́ípadě věřím...

36 Jak tvrdí prof. P. Vopěnka v rozhovoru pro Salon Práva, 26. března 2014. https://www.novinky.cz/kultura/salon/331332-dnesni-skolstvi-nas-tahne-dolu-rika-matematik-a-filosof-petr-vopenka.html.

37 Netuším, proč mi právě tady naskočila asociace na jednoho třídně uvědomělého „lidodemo“ školitele, který na jakémsi aktivu burcoval k boji za „lepší prríští“ slovy „,zdohnat a předzdohnat“, při nichž jsem si pouze pomyslel „,no, s Tebou určitě...".

38 Jako by se místo dřivějšího „poroučení větru, dešti, bouři“ chtělo poručit tentokrát Gaussově křivce četnosti (aplikované na rozložení inteligence v populaci) a silou „vưle a představy“ učinit masovou vzdělanostní „elitu“ z většiny národa. 
právo je prostě pojmově spojeno s vysokými nároky na faktografii (znalosti reáliii ${ }^{39}$ ), aniž slevuje z vysokých nároků na abstraktní pojmové myšlení. ${ }^{40}$

Málem „celonárodni““ diskuse kolem standardu maturit je jen pars pro toto. Inflaci podléhá i nezávislé testování nejen u maturit, ale i u různých přijímacích, postupových a závěrečných zkoušek. Standard se nezrrídka přizpůsobuje uchazečům a je funkcí jejich schopností, namísto aby šlo o nepřekročitelný parametr a filtr oddělující v důsledku ty způsobilé od zbytku. Těch obsahových standardů, jejichž dosažení se masově předpokládá (typicky pod heslem „maturitu všem, dokonce Vergilia v originále skladníkům do šroubáren“), nemůže dosáhnout student bez motivace. Tu však nelze vnutit, když student ví, že má při takovém „studiu“ zájem jen o certifikát umožňující mu vykonávat profesi, o niž má skutečný zájem a k níž „zbytečnosti“ nepotřebuje.

Stejně jako maturita, tak i postupová zkouška či zkouška závěrečná může být bud’ kvalitní, nebo „pro všechny“. Je-li nap̌r. maturita „pro všechny“, nemá způsobilost osvědčit způsobilost studovat na vysoké škole. Pokud ano, může na vysoké škole studovat každý? No teoreticky jistě, ale na „vysoké“ škole jaké úrovně a jakých nároků? Významná část populace na maturitu prostě dosáhnout nemá, pokud má maturita plnit funkci diferenciace populace na studijně disponovanou část a část nestudijní. Jinak ztrácí maturita smysl. ${ }^{41}$ Kromě latentní a oportunní trivializace lze pozorovat i zcela otevřené snahy o banalizaci všech zkoušek a zpochybňování standardů náročnosti (á la: vždyt' nezáleží na maturitě, ani na státnicích, nebot' to jsou v podstatě jen formality a obřadní kroky,

39 Jak konstatuje i prof. P. Šámal (v rozhovoru pro časopis Soudce, 2019, č. 5, s. 11), schopný právník musí nosit určité pensum znalostí v hlavě a neměl by podléhat dojmu, že na webu najde vše potřebné.

40 Překvapila mě stížnost jednoho studenta, že po nich na cvičeních z obchodního práva (kde se skutečně řeši konkrétní př́klady, po čemž se jindy volá) vyžaduji, aby předtím doma přečetli př́liš velký počet konkrétních př́kladů a prokázali detailní znalosti předpisů potřebných $\mathrm{k}$ jejich vyřešení, takže nestíhají svoje ,jiné vedlejší aktivity“. Za prŕklad hodný následování mi doporučil jeden nejmenovaný předmět spíše hodnotově teologického charakteru, kde se dopředu jen zadá obecný problém a na hodině si o něm všichni „,tvořivě popovídaji“, což rozvíji jejich „soft skills“. Opáčil jsem mu, že bych se nechtěl dostat do rukou takto obecně „,vycvičeného“ advokáta-mluvky, nebo podobně kvalifikovaného chirurga; že odborný život je vždy až nepř́ijemně konkrétní a mimoto že na zahraničních západních univerzitách je domácí př́íprava na výuku ještě mnohem náročnější. Že „vznešená hodnotová argumentace“ a „nejrůznější zajímavé právní konstrukce“ bez „znalostních cihel““ nejsou k ničemu, podobně jako nelze porozumět fyziologii a patologii bez anatomie a biochemie.

41 SMRČKA, L. Maturitni masakr? Ale kedeže... Dostupné z: http://neviditelnypes.lidovky.cz/spolecnost/skolstvi-maturitni-masakr-ale-kdeze.A180606_232540_p_spolecnost_wag; Autor si klade otázku, co máme očekávat, pokud přijmeme sedmdesát procent populačního ročníku na (střední) školu, na jejímž konci je „výběrová zkouška“, kterou má průměrně inteligentní člověk složit pouze při souběžně vysoké píli. Nedostatek vysoké píle je přitom podstatně častější než přebytek inteligenčních schopností. Vysoké procento lidí s maturitou v populaci nesvědčí o kvalitě jejich vzdělání, ale o nekvalitě maturitní zkoušky, jak prohlašuje BÍLEK, P. Neumíte psát? Nepište! Literárni noviny, 11. ledna 2019. 
které se musejí absolvovat ${ }^{42}$. Tomu nelze ustupovat bez ztráty sebeúcty a bez špatného svědomí o společenské odpovědnosti a o smysluplnosti učitelské práce, jež nespočívá v prríspěvku k pavzdělanosti. ${ }^{43}$

Nevím, kolik je mezi námi takových št’astlivců, co nezažili pocit morální kocoviny ze zkoušky, kterou studentovi nakonec dali, ač přitom skř́pali zuby a připadali si (v lepším př́padě) jako instrumentalizovaná dekorace. Kdyby totiž učitel neustoupil a držel si svůj standard požadavků, vypadal by jako deviant on, protože ostatní kolegové (nebo obory) mají tyto nezpơsobilé studenty za vyhovující; a nakonec to přece „taky jde“. Kdo nesleví z daných nároků, zpytuje se nejednou sám: nejsem nakonec nějak divný já?

Jsem příznivec participace studentů na formování obsahu výuky a velmi stojím o zpětnou vazbu, kterou si jako vyučující zprostředkovávám v reprezentativnější podobě, než umožňují studentské ankety na ISu. Student však není zákazník a pán, kterému bychom se měli podbízet a jemuž by se mělo populisticky lichotit a jenž by měl z přednášek a cvičení odcházet pokud možno neunaven, ale především osvěžen a pobaven. ${ }^{44}$

Řeči o přetíženosti studentů, jež proto (!?) vyžaduje snížení nároků, nejsou př́liš dojímavé a zavánějí pokrytectvím. Zatímco dřive (odhaduji před 10-15 lety, pozn. JB) pracovalo při studiu práv cca $15 \%$ a zbytek víceméně jen studoval, dnes je to naopak. ${ }^{45}$ Mưže to samozřejmě občas být i ekonomická nutnost nebo sebeedukativní nástroj; častěji ale půjde spíše o prachobyčejnou snahu zajistit si vyšší životní úroveň ještě v průběhu studia (či v důsledku třeba i na úkor jeho rozsahu, hloubky a kvality). Měli bychom se jako učitelé snažit, aby žádná znalost či dovednost vštěpovaná studentům nebyla samoúčelná a zbytečná, ale neměli bychom o tom nechat rozhodovat studenty. ${ }^{46}$ Učitelé,

42 Student 5. semestru mě přesvědčoval, že nároky kladené u zkoušek v 6. semestru jsou vysoké, a že „,filtrovat" se má na začátku studia (rozuměno: tedy ne už v ročníku jeho). Oponoval jsem, že by to bylo velmi demotivační a demoralizující a že život nás „filtruje“ stále a průběžně a škola je k tomu mj. vhodnou průpravou.

43 Termín používá GRIM, T. Soumrak českého školství? Vesmír, 2018, č. 1. Dostupné z: https://vesmir.cz/ cz/on-line-clanky/2018/01/soumrak-ceskeho-skolstvi.html

44 Ujal se dokonce termín edutainment (jako kombinace education a entertainment). Osobnostní učitelský profil „nenáročného šoumena“ je ideální a měl by se asi testovat ve výběrovém řízení na pedagogy. Náročných šoumenů bude asi pomálu, na rozdíl od průměrně náročných sucharů.

Vzpomněl jsem si v této souvislosti na jednu ze svých dřivějších demoralit:

Maximálni cíl pedagoga: vabudit výkladem takový zájem a nadšeni, že student zatoužípo dalšim samostudiu.

Minimálni cil: vyvolat takovou briqu z.predmètu a zmateni, že student je nucen pristoupit k samostudiu. Je tréba opravdu velké prostrednosti, aby pedagog neumél alespoň jednobo pólu dosábnout a aby se jeho studenti neučili...

45 URBAN, M. Studenti by měli na fakultě dostat více právnické potravy, aby za ní nemuseli utíkat jinam. Srov. https://www.pravniprostor.cz/clanky/ostatni-pravo/rozhovor-judr-michal-urban-studenti-by-meli-na-fakulte-dostat-vice-pravnicke-potravy-aby-za-ni-nemuseli-utikat-jinam

46 Byl jsem mj. rovněž (coby mj. celoživotní právní praktik) adresátem poučení (od studenta v prvé polovině studia) o tom, co je třeba $\mathrm{v}$ mém předmětu vyučovat $\mathrm{z}$ hlediska ,potřeb právnické profese $\mathrm{v}$ kontinentální právní kultuřre“. 
a ne studenti, rozhodují o nárocích a jsou také povinni je garantovat. „Pokud se některý student citi na škole pretížen, na danou školu nepatř. " 47

Jsem rád, že se nám na fakultní „práva vinici Páně“ podařilo v minulosti nemálo pozitivního. Pozitiva spočívala nejednou i v zábraně nesmyslům. Se zadostiučiněním i hořkou pachutí vzpomínám, jak jsme se ve druhé polovině devadesátých let bránili a ubránili nepromyšlenému plošnému zavádění boloňského procesu, ${ }^{48}$ spojenému s nevybíravým vrchnostenským nátlakem včetně hrozeb rozpočtových restrikcí za neposlušnost; ${ }^{49}$ s obavou pozoruji náběhy na historií nezatíženou recidivu v současnosti, jen ukrývanou pod jinými názvy.

Nevěřím opakovaně pronášeným (,politicky korektním“ a přitom až komicky dadaistickým) proklamacím z „vyšších míst“ univerzity, že vyšší počet studentů neznamená pokles jejich kvality. V rozpacích se již delší dobu „kroutíme“ při požadavcích na „zvýšení studijní úspěšnosti“, které prritom jsou jen implicitním přiznáním nepravdivosti a pokrytectví explicitně tvrzených proklamací uvedených na začátku odstavce.

Jsme občas vystaveni tlaku na ,zprůmyslovkařeni““ výuky práva tzv. technicistně dovednostními předměty; ty je třeba udržet na uzdě ve velmi omezeném rozsahu - nejsme přece (aspoň ne především, ale jen z malé části) Fachhochshule typu justiční akademie. Role fakulty je komplexnější nežli sloužit jen jako lepší školní přípravka orientovaná výlučně na praxi.

Potácíme se v kvantifikovaných ukazatelích své kreativity: mezi přesvědčováním odosobněného „systému“ o malé či žádné vypovídací schopnosti tohoto „vědoměru“ a vzýváním vlastní sebeúcty, že „méně je přece více“, i kdybychom na tom měli být biti.

Anketní hodnocení učitelů studenty jsou jistě užitečná; občas se však od nich dozvídáme překvapivé věci nap̌r. o zabíhavosti a teoretičnosti výkladů, když oni přece očekávají praktické manuály a vypínají pozornost, jakmile učitel řekne „tady je zajímavý teoretický problém“ (vždyt' to jim přece v praxi k ničemu není...).

Musíme občas bojovat proti nedůvtipné a krátkozraké „sloganové politice“ připomínající dřívější schválená hesla do prvomájových průvodů..$^{50}$

47 BÍLEK, P., op. cit.

48 Ten předpokládal mj. povinné rozdělení studia na bakalářský a magisterský stupeň. Politicko-korektnímu žargonu („povinná vertikální diferenciace právnického univerzitního studia“) bylo přitom tak snadné (a výhodné) podlehnout...V Německu se tehdy zformovala velmi silná intelektuální opozice, která zavedení tohoto nesmyslu u nich zabránila (srov. „Landesburger Manifest“ Spolku německých právníkủ z r. 1999, na nějž upozorňuje HOLLÄNDER, P. Dilemy právnického v₹delávania. Nepublikovaný př́íspěvek na konferenci v řijnu 2018 v Košicích, s. 8).

49 Pazvuky totalitní politické kultury nás tehdy zasáhly velmi silně; šlo o jednu z věcí, o nichž se podobně jako o mnoha otázkách před listopadem 1989 „prostě nediskutuje“.

50 Viz třeba zaklínadlo „internacionalizace“, podrývající při násilné a nedomyšlené aplikaci už tak narušenou a křehkou kontinuitu bádání o právu (srov. tzv. povinné cizojazyčné habilitace, jimž jsme se nakonec ubránili). 
Je asi př́liš optimistické vyzývat ke zvyšování náročnosti studia, když tolik objektivních faktorů takovému cíli protiřečí. I kdyby nám „nic“ nebránilo, velmi pravděpodobně se najde aspoň „někdo“, kdo za ono „nic“ ochotně zaskočí. Zvyšovat nároky na sebe sama, což je asi s náročností na druhé spojeno (jinak by šlo o samoúčel), je v takovém prrípadě sebedestruktivní a sebediskriminační. Přeji fakultě, aby takové „žáby na prameni“", bránící zvyšování náročnosti (té na sebe, ale i náročnosti na ostatnî) negenerovala, ale aby je motivovala a vedla k opaku, nebo je aspoň vyřazovala z odpovědných míst.

Zvyšování náročnosti studia neznamená nutně neustálé reformy. Abstraktní vyznávání reforem nesmí být ideologií současnosti. Kdo zcela určitě (!) neví, zda by se něco nemělo změnit, prostě to změnit nesmí.

Jen velmi bohatá anebo velmi hloupá země si může dovolit vypracovávat pro každou generaci studentů nové pojetí studia; ${ }^{51}$ to jistě platí i pro fakulty právnické, které by měly kontinuálně navazovat na předchozí pojetí a změny prosazovat spíše v konzervativním ladění a s přesvědčivým zdůvodněním. Přeji fakultě reformátory (pokud nějaké, tak právě takové) osvícené, odvážné, nekonjunkturální a nezideologizované, kteří ani v postmoderní době flexibility, prchavosti, pomíjivosti a mnohoznačnosti pojmů a celkové dekonstrukce neztratí zdravě konzervativní kompas a budou uvážlivě pracovat nejen s výzvami budoucnosti, ale i s odkazem minulosti. ${ }^{52}$

\section{Úmèrnè citová zdravice na počest stoleté mladice (douskea)}

Kulatá jubilea svádèji k ikonizaci jmen či názvư oslavovanébo, jebo označeni rünými znaky, standardami a logy; obvykle se také klisovitě chváli stav fyzické schránky či budov oslavence a jejich vybavení.

Podobné vnèjsí znaky nejsou však podstatné ani u institucí, ani u lidí. Tyto atributy se ostatné i u naši právnické fakulty a jeji univerzity za sto let vícekerát żmènily. Co pretrvává, jsou ideje, charakter a výsledky, jimižjubilant ovlivnil život kolem sebe. Jejich nositeli jsou ve škole hlavně učitelé a akademické vedeni, správni zamèstnanci a studenti.

Myslím, že Právnická fakulta MU má celkovou stoletou bilanci vysoce kladnou a že na ni mưžeme být hrdi. Je povznnášejici (ale současně i skličujici) uvédomit si, ře jižpo téměr polovinu jeji stoleté historie jsem s ni osobně spjat.

Priznávám se ke dobrému pocitu nad jejím rozvojem a nad jejimi výsledky a jsem rád za možnost ke nim snad drobně prispèt. Přeji své institucionálni celoživotni souputnici

51 LIESMANN, K. P. Teorie nevzdělanosti. Omyly společnosti védéní. Praha: Academia, 2008, s. 115.

52 Moderním žargonem path dependence... 
(tedy predevš́m tèm, kdo rídi a budou ovlivňovat jeji bèh a zejména učiteliom) dloubou viili ke odporu vĩci stagnaci, ale i imunitu ke ideologicky motivovanému úsilí o zlepš̀eni svètabèbu, ${ }^{53}$ prejej sílu ke náročnosti na sebe i na kvalitu „výstupü“.

Necht' škola prispivá ke rozvoji právni nauky a ke kultivaci normotvorby, jakož $i$ ke úrovni aplikačni praxe. At' odbornè vychovává i lidsky formuje vysoce vzdèlané, kultivované a motivované absolventy, kteři na ni budou moci být vždy brdi (a snad i s podobným pocitem vděčnosti, jejž zaživám já).

53 Srov. deprimující svědectví o „politicko-korektní“ ideologizaci z pera německého profesora hostujícího na špičkové univerzitě v Harvardu (mj. o hypertrofii módních zaklínadel typu „identitární politiky“, „varovných spouštěčü“, „mikroagrese“, „bezpečných prostor“, „toxické maskulinity“ apod.). MEYER, A. Diversität zählt mehr als Wahrheit: Wie sich Akademie ins intellektuelle Abseits manövriert. Neue Zürcher Zeitung, 12. 9. 2018. Snad se u nás vyhneme rovněž „kulturní válce“ mezi samozvanými bojovníky za „sociální spravedlnost“ a zastánci svobody projevu, která se rozhořela na řadě amerických universit. Srov. NEUMANN, M. Zensur an der Uni? „Nicht jetzt, nicht hier“. Neue Zürcher Zeitung, 23. 5. 2019. 